\title{
A new species and a new record of Curcuma subgen. Curcuma (Zingiberaceae) from Northern Thailand
}

\author{
SURAPON SAENSOUK ${ }^{1, \boldsymbol{\nu}}$, THAWATPHONG BOONMA ${ }^{2}$, PIYAPORN SAENSOUK ${ }^{3}$ \\ ${ }^{1}$ Plant and Invertebrate Taxonomy and Its Applications Unit Group, Walai Rukhavej Botanical Research Institute, Mahasarakham University. \\ Kantarawichai District, Maha Sarakham, 44150, Thailand. `email: surapon.s@msu.ac.th \\ ${ }^{2}$ Brio Botanical Research Garden, 53 M.5 Ban Mai Village, Phikun Ok, Ban Na District, Nakhon Nayok, 26110, Thailand \\ ${ }^{3}$ Plant and Invertebrate Taxonomy and Its Applications Unit Group, Department of Biology, Faculty of Science, Mahasarakham University. \\ Kantarawichai District, Maha Sarakham, 44150, Thailand
}

Manuscript received: 11 July 2021. Revision accepted: 5 August 2021.

\begin{abstract}
Saensouk S, Boonma T, Saensouk P. 2021. A new species and a new record of Curcuma subgen. Curcuma (Zingiberaceae) from Northern Thailand. Biodiversitas 22: 3617-3626. Recent fieldwork to study the species diversity of the Zingiberaceae family in Thailand and preparing a revision of the Curcuma genus for the Flora of Thailand, an undescribed species of Curcuma uses as traditional medicinal for more than two decades well known in the Thai vernacular name "Rang-Jued" was found, this vernacular name is also used to call the other two medicinal plants belonging to different families which are Thunbergia laurifolia Lindl. (Acanthaceae), and Crotalaria spectabilis Roth (Fabaceae), thus some villagers are named Curcuma rangjued as "Rang-Jued-Khamin" to communicate specifically identify species in order to use correct species for each utilization. While Thunbergia laurifolia was called "Rang-JuedThao", which "Thao" means "vine" refers to its habit and Crotalaria spectabilis was called "Rang-Jued-Ton" which "Ton" means "stem" refers to its erect stems. After comparing this undescribed species of Curcuma with its allies species, we found that this species did not match with any existing taxa, thus described with detailed illustrations, photographs, summaries for its distribution, ecology in the name of Curcuma rangjued Saensouk \& Boonma and followed by a new record of $C$. cordata Wall. for Thailand which in the past has been determined as a synonym of $C$. petiolata Roxb. but now it is back to a recognized name once again. Both species in this study were found distributed in the northern region of Thailand and belong to Curcuma subgenus Curcuma, their description along with ecology, phenology, and a revised key to 28 species of Curcuma subgenus Curcuma in Thailand are also present for facilitating identification.
\end{abstract}

Keywords: Curcuma, new species, new record, taxonomy, Zingiberaceae

\section{INTRODUCTION}

Turmeric (Curcuma longa) and many species of Curcuma have been used to treat sprains and swelling throughout history for various purposes for many millennial years, many natural products have biological and pharmacological as prescribed by Ayurveda (Araujo \& Leon 2001). Curcuma L. belongs to the family Zingiberaceae and is divided into three subgenera namely subgen. Curcuma, Hitcheniopsis, and Ecomatae (Záveská et al. 2012; Leong-Škorničková et al. 2015) with more than 130 species of Curcuma in the world were recognized (http://apps.kew.org/wcsp/).

Thailand is one of the species diversity hotspots for the Curcuma genus with the latest reported 67 species distributed throughout the country and comprised of 23 species belong to subgen. Hitcheniopsis, 18 species of subgen. Ecomatae, and 26 species of subgen. Curcuma (Larsen and Larsen S.S. 2006; Sirirugsa et al. 2007; Saensouk et al. 2021a, 2021b). In this study, the undescribed species of Curcuma uses as traditional medicinal for more than two decades well known in the Thai vernacular name "Rang-Jued" was found while investigating the species diversity of the Zingiberaceae family in Northern Thailand. After comparing it with its allies species, we found that this species did not match with any existing taxa, hence described and illustrated here as new species to science.

And a new record of Curcuma cordata Wall. for Thailand. This species was first published as new species to science in 1829, in Plantae Asiaticae Rariores by Nathaniel Wallich with its descriptions, habitat, taxonomic treatment, and comparison to the most similar species, Curcuma petiolata Roxb., both species are reported from Myanmar. Later in 1894, C. cordata Wall. was placed as a synonym of Curcuma petiolata Roxb. in The Flora of British India Volume VI. - order CXLIX. SCITAMINEAE by J. G. Baker (p. 216). This caused $C$. cordata Roxb. was identified as a synonym of $C$. petiolata all along, both in the specimens collected in herbariums and other relevant research studies in Thailand. Until 2010, LeongŠkorničková J. and her colleagues published the result of their study towards the stability of names in Indian Curcuma L. (Zingiberaceae). The result presents Curcuma petiolata Roxb. (Fl. Ind. 1: 36. 1820) as an accepted name with only Curcuma cordifolia Roxb. as a synonym (Hort. Beng.: 1. 1814, nom. nud.; Fl. Ind. ms. 43; Fl. Brit. India: 216. 1890) but did not appear the name of C. cordata Wall. (Leong-Škorničková et al. 2010). Later in 2015, LeongŠkorničková et al. also supported Curcuma cordata Wall. as an accepted name belongs to Curcuma subgenus Curcuma (Leong-Škorničková et al. 2015). 
More than a century, $C$. cordata Wall. has been a synonym but now it is back to a recognized name once again. While investigating fieldwork to study the species diversity of the Zingiberaceae family in Thailand and preparing a revision of the Curcuma genus for the Flora of Thailand this species was found distributed in Mae Hong Son Province, Northern Thailand. We examined the living samples and comparing them with the existing taxa, they were found to be the same as Curcuma cordata Wall. Several samples of this plant were also collected by other collectors from Mae Hong Son Province in the nearby areas and specimens were kept at QBG Herbarium, but those specimens were mistakenly identified as Curcuma petiolata Roxb. (Detailed in the specimens examined below). Moreover, we also compare them with many specimen collections of Curcuma cordata Wall. from Myanmar which is available online on the National Museum of Natural History website (detailed in the specimens examined below). Investigating and collecting data from past studies to the present, no record of Curcuma cordata Wall. in Thailand. We, therefore, the first report here for a new record of Curcuma cordata Wall. for Thailand. Its description along with ecology, phenology, and a revised key to 28 species of Curcuma subgenus Curcuma in Thailand for facilitating identification is present.

\section{MATERIALS AND METHODS}

Plant materials and photographs were collected from 2017 to 2021 from Mae Hong Son Province, northern Thailand [Mae Hong Son Province, Mae Sariang District, 04.08.2017, T.Boonma 9 (holo KKU!; iso QBG!, BK!, BKF!, BBRG!); Mae Hong Son Province, Mae Sariang District, 415 m, 18.09.2019, T.Boonma 17 (KKU) and living specimens have been planted at Brio Garden (BBRG) in Nakhon Nayok Province] and additional specimens were also compared. The descriptions of morphologically similar species and related information, Curcuma longa L. (Sabu M. 2006), C. sichuanensis (Chen X.X. 1984), C. amada (Roxburgh 1810; Sabu M. 2006), C. cordata (Roxb.1829; Leong-Škorničková et al.2015), $C$. petiolata (Roxburgh 1820; Larsen and Larsen S.S. 2006; Sirirugsa et al. 2007; Leong-Škorničková et al. 2010), and type specimens housed in various herbaria $(\mathrm{BK}, \mathrm{BKF}, \mathrm{K}$, KKU, QBG, US), digital images, and photos of dry specimens available online in the National Museum of Natural History (NMNH), including all existing published literature of Curcuma especially in subgenus Curcuma were compared.

\section{RESULTS AND DISCUSSION}

During the fieldwork to study the species diversity of the Zingiberaceae family in Thailand and preparing a revision of the Curcuma genus for the Flora of Thailand, a new species $C$. rangjued sp. nov. (Figures 1-3 and Tables 1) and a new record of $C$. cordata (Figure 4) have been found. Both species belong to subgen. Curcuma and described here with the taxonomic treatment, description, detailed illustrations, photographs, summaries for its distribution, ecology, and notes, followed by a new record and revised key to 28 species of Curcuma Subgen. Curcuma in Thailand is provided for facilitating their identification.

\section{Taxonomic treatment}

Curcuma rangjued Saensouk \& Boonma, sp.nov. Figures 1-3, Table 1 -subgenus Curcuma

Curcuma rangjued is belonged to the subgenus Curcuma according to the presence of epigynous glands, inflorescence with coma bracts, flowers closed-form, anther spurs acute and downward-pointed. The morphological description in having rhizome pale yellow tone internally and producing terminal inflorescence of $C$. rangjued make it similar to $C$. amada and $C$. sichuanensis, but differ in having non-aromatic rhizome whereas $C$. amada and $C$. sichuanensis having a smell of green mango and smell of camphor respectively. Moreover, in having leaf-adaxially sparsely hairy along the vein, peduncle long 25-37 cm long, less number of fertile bracts (7-12 per inflorescence), calyx light pale yellow, $1.64-1.75 \mathrm{~cm}$ long, floral tube $3.3-3.5 \mathrm{~cm}$ long, corolla lobes hairy at distal part and anther spurs 3-4 mm long which distinguishes $C$. rangjued from $C$. amada and $C$. sichuanensis (Table 1).

Type: THAILAND, Mae Hong Son Province, Mae Sariang District, 04.08.2017, T.Boonma 9 (holo KKU!; iso QBG!, BK!, BKF!, BBRG!)

Perennial herb. Rhizome ovoid, non-aromatic, brown externally, pale yellowish-white internally with darker core (lighter in dormancy or after harvesting), 3-5 × 4-7 cm, with 2-4 branched rhizome occurs on two opposite sides, straight out from the primary rhizome and develop into a new shoot at the tip, brown externally, two layers internally, pale yellowish-white with darker core, 3-10 cm long, 1-2 cm in diameter, with a sub-branched rhizome downward, branched rhizome covered by white triangle scales and turned to brown while growing. Root fibrous with tuberous roots. Leafy shoot $70-110 \mathrm{~cm}$ tall. Bladeless sheaths 1-2, green, wilt while growing. Leaf-sheaths green, distichous, (10-)20-38 cm long; ligule short and thin, 0.8-2 $\mathrm{mm}$ long; petiole green, canaliculate, (10-)14-25 cm (except the first leaf has the shortest petiole $1.5-3 \mathrm{~cm}$ ), glabrous. Lamina 5-7, narrowly elliptic to oblanceolate, (17-)30-60 × (8-)12-17 cm (the first leaf shortest and narrowest), apex acuminate with slightly cordate, base attenuate, equal, margin entire, hyaline, translucent white, adaxially green, sparsely hairy along the veins, abaxially paler green, glabrous. Inflorescence terminal emerges almost distal part of the pseudostems; spike conical, tapered at the base and spread at distal part, 14-18 cm long, ca. $6 \mathrm{~cm}$ in diam. in the middle; peduncle pale green, 25-37 $\mathrm{cm}$ long, very short fine hairy. Coma bracts narrowly obovate, $5-8 \times 1.5-2.8 \mathrm{~cm}$, lower obtuse apex, upper slightly mucronate apex, margin hyaline, white with pinkish-purple tip (gradually fade to white at base), finely hairy on both surfaces. Fertile bracts $7-12$ in number, ovate, 3.8-4.5 × 1.5-2 cm, apex obtuse, margin hyaline, 
very light pale green, upper bracts with a pinkish-purple tip as coma, finely hairy on both surfaces. Flower yellow. Bracteoles translucent yellowish-white, rarely with very pale pink tinge at the tip, obovate, $1.5-3.3 \mathrm{~cm}$ long, apex obtuse, hooded, sparsely hairy (hairier at distal part). Calyx light pale yellow, 1.64-1.75 cm long, apex 3-lobed with unilateral incision up to $9 \mathrm{~mm}$ long, sparsely hairy. Floral tube tubular, 3.3-3.5 cm long, pale yellow; dorsal corolla lobe 1, triangular-ovate, $1.8-2 \times 1.7-2 \mathrm{~cm}$, hooded, apex mucronate with mucro $2.8 \mathrm{~mm}$ long, white or very pale yellow, sparsely hairy at distal part; lateral corolla lobes 2 , triangular-ovate,1.3-1.6 × 1.1-1.4 cm, apex obtuse with few hairy at distal part. Lateral staminodes 2 , asymmetrical obovate, $1.7-2.1 \times 0.9-1.1 \mathrm{~cm}$, apex rounded to obtuse, pale yellow, outer glabrous, inner surface pubescent in the middle lobe. Labellum obovate, $2.2-2.4 \times 1.6-1.8 \mathrm{~cm}$, apex emarginate with an incision $1.5-2.5 \mathrm{~mm}$, yellow with the dark yellow patch. Stamen 1, light pale yellow; filament flat 4-4.2 mm long. Anther 5.4-6 mm long, spurred; spurs at base 3$4 \mathrm{~mm}$ long; crest yellow, apex obtuse. Stigma conical, glabrous, ostiole ciliate. Epigynous glands 2, 5-6 mm long, apex acute, pale yellow. Ovary subspherical, 2.5-3 $\times 2.5-3$ $\mathrm{mm}$, pubescent. Ovule axile placentation. Fruit and seeds not seen.

Vernacular name: "Rang-Jued" in Thai language.

Phenology: Flowering in the rainy season (June to October); flowers open in the morning and last a single day. Leafy shoot emerging in late April and dormancy begins in November.
Distribution: Mae Sariang District, Mae Hong Son Province, Thailand, and cultivated throughout Thailand.

Etymology: The specific epithet "rangjued" is derived from Thai vernacular name of this species which means "to make the poison fade or decrease".

Uses: Thai traditional medicinal use its mature rhizomes (fresh) to treat poisoning, detoxification, and antiinflammation (Oranuch K. 2007).

Notes: The vernacular name "Rangjued" is also used to call the other two medicinal plants belonging to different families which are Thunbergia laurifolia Lindl. (Acanthaceae), and Crotalaria spectabilis Roth (Fabaceae), thus some villagers are named Curcuma rangjued as "Rang-Jued-Khamin" to communicate specifically identify species in order to use correct species for each utilization. While Thunbergia laurifolia was called "Rang-Jued-Thao", which "Thao" means "vine" refers to its habit, and Crotalaria spectabilis was called "Rang-Jued-Ton" which "Ton" means "stem" refers to its erect stems. In our survey, only one natural habitat was found in Mae Sarieng District, Mae Hong Son Province, northern Thailand, and cultivated throughout the country, especially grow for wholesale to the herb's market and there is still a large demand for the use of traditional medicine. Due to the information about distributions and number of mature in the natural habitat of this species is still insufficient for proper assessment of conservation status as Data deficient (DD). Further fieldwork and observations are needed to assess changes in population, distribution, and abundance in the future.

Table 1. Morphological comparison of Curcuma rangjued, C. sichuanensis, C. longa, and C. amada

\begin{tabular}{|c|c|c|c|c|}
\hline Characters & Curcuma rangjued & $\begin{array}{c}\text { Curcuma amada } \\
\text { (Roxburgh 1810; Sabu 2006) }\end{array}$ & $\begin{array}{c}\text { Curcuma sichuanensis } \\
\text { (Chen 1984) }\end{array}$ & $\begin{array}{c}\text { Curcuma longa } \\
\text { (Sabu 2006) }\end{array}$ \\
\hline Rhizome-size & $4-7 \times 3-5 \mathrm{~cm}$ & $4-5.3 \times 3-4 \mathrm{~cm}$ & $2-4 \times 1-2 \mathrm{~cm}$ & $2-3 \times 2-3 \mathrm{~cm}$ \\
\hline Rhizome-smell & Non-aromatic & Smell of green mango & Smell of camphor & Strongly aromatic \\
\hline $\begin{array}{l}\text { Rhizome } \\
\text { internally }\end{array}$ & Pale yellowish-white & $\begin{array}{l}\text { Light yellow, white } \\
\text { towards the periphery }\end{array}$ & Pale yellow & Deep orange-yellow \\
\hline Leaf-adaxially & Sparsely hairy along the vein & Glabrous, tip hairy & Glabrous & Glabrous, tip hairy \\
\hline Leaf-abaxially & Glabrous & Puberulous & Glabrous & Glabrous \\
\hline Leaves-base & Attenuate, equal & Equal & Attenuate, oblique & Cuneate \\
\hline Inflorescence & Terminal & Terminal and lateral & Terminal & Terminal \\
\hline Peduncle & $25-37 \mathrm{~cm}$ long & $20-22 \mathrm{~cm}$ long & $15 \mathrm{~cm}$ long & C. $15 \mathrm{~cm}$ long \\
\hline Coma-surface & $\begin{array}{l}\text { Finely hairy on both } \\
\text { surfaces }\end{array}$ & Pilose on both surfaces & $\begin{array}{l}\text { Glabrous inside, outside } \\
\text { pubescent }\end{array}$ & $\begin{array}{l}\text { Pubescent on both } \\
\text { surfaces }\end{array}$ \\
\hline Coma-color & $\begin{array}{l}\text { White with pinkish-purple } \\
\text { tip (gradually fade to } \\
\text { white at base) }\end{array}$ & Light violet & $\begin{array}{l}\text { Lower half white, } \\
\text { sometimes slightly } \\
\text { purple-red apically }\end{array}$ & White with green at tip \\
\hline Fertile bracts & 7-12 per inflorescence & 15-18 per inflorescence & $18-25$ per inflorescence & 25-30 per inflorescence \\
\hline Bract-surface & Finely hairy on both sides & Pilose on both surfaces & Glabrous on both sides & $\begin{array}{l}\text { Inner glabrous, } \\
\text { Outer minutely pubescent }\end{array}$ \\
\hline Bract-color & $\begin{array}{l}\text { Very light pale green, } \\
\text { upper bracts with pinkish- } \\
\text { purple tip as same as } \\
\text { coma bract }\end{array}$ & Green & Green & Pale green \\
\hline Calyx & $\begin{array}{l}\text { Light pale yellow, } \\
1.64-1.75 \mathrm{~cm} \text { long }\end{array}$ & $\begin{array}{l}\text { White, } \\
1 \mathrm{~cm} \text { long }\end{array}$ & $\begin{array}{l}\text { White, } \\
1 \mathrm{~cm} \text { long }\end{array}$ & $\begin{array}{l}\text { White, } \\
1 \mathrm{~cm} \text { long }\end{array}$ \\
\hline Floral tube & $\begin{array}{l}3.3-3.5 \mathrm{~cm} \text { long, pale } \\
\text { yellow, glabrous }\end{array}$ & $\begin{array}{l}3 \mathrm{~cm} \text { long, pale yellow, } \\
\text { Minutely pubescent }\end{array}$ & $\begin{array}{l}2.5 \mathrm{~cm} \text { long, yellowish, } \\
\text { Glabrous }\end{array}$ & $\begin{array}{l}2.5 \mathrm{~cm} \text { long, white, } \\
\text { Glabrous }\end{array}$ \\
\hline Corolla lobes & Hairy at distal part & Glabrous & Glabrous & Glabrous \\
\hline Anther spurs & 3-4 mm long & 1-2 mm long & $1-2 \mathrm{~mm}$ long & $3 \mathrm{~mm}$ long \\
\hline Epigynous glands & 5-6 mm long & $6 \mathrm{~mm}$ long & $4.5 \mathrm{~mm}$ long & $5 \mathrm{~mm}$ long \\
\hline Ovary & 2.5-3 mm long, pubescent & $3 \mathrm{~mm}$ long, densely hairy & $5 \mathrm{~mm}$ long, villose & $5 \mathrm{~mm}$ long, pubescent \\
\hline
\end{tabular}



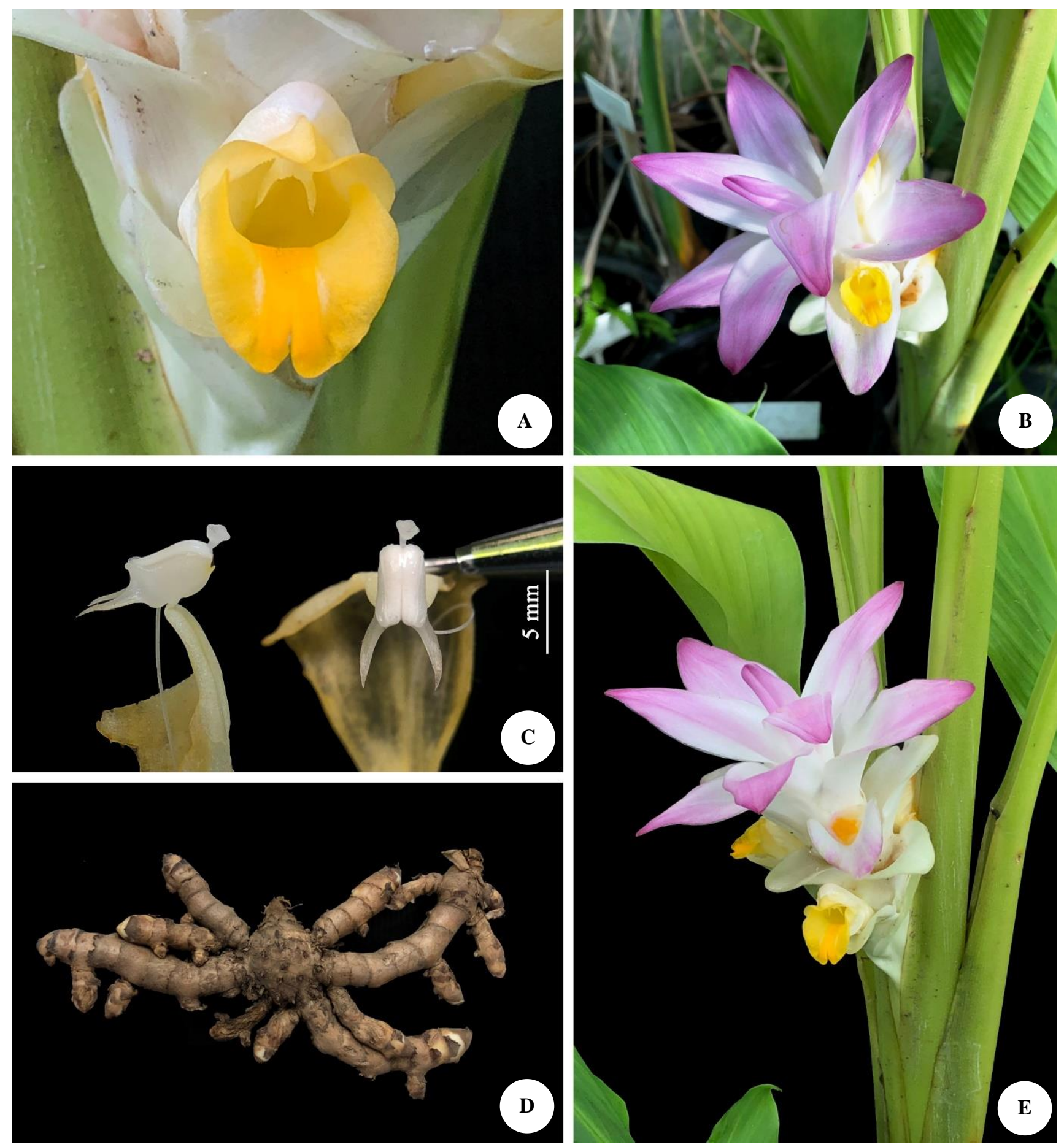

Figure 1. Curcuma rangjued Saensouk \& Boonmasp. nov. (A) flower-top view, (B) inflorescence with flowers-top view, (C) anther side and front view, (D) rhizome, (E) inflorescence with flowers - side view. Photographed by Thawatphong Boonma. 


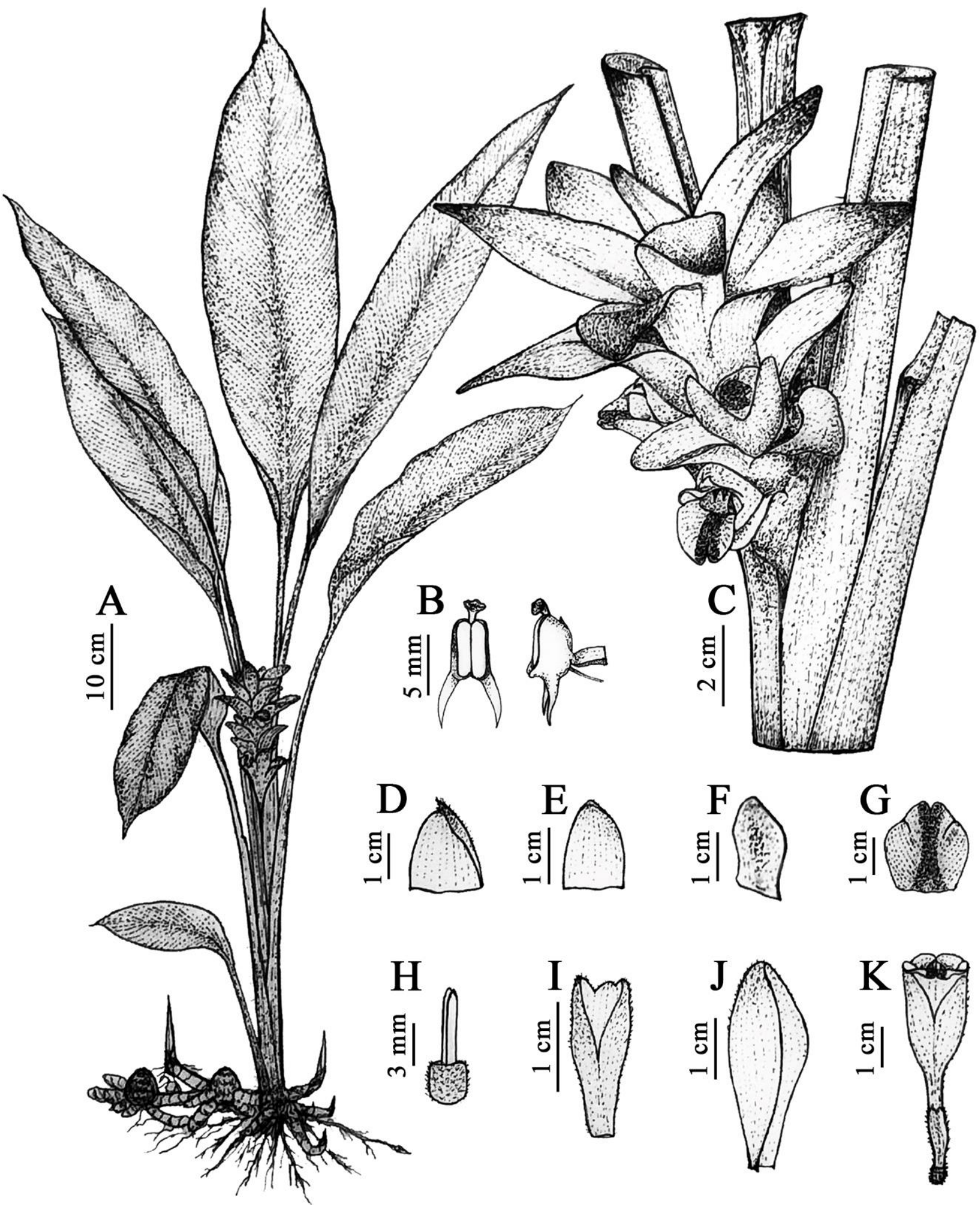

Figure 2. Curcuma rangjued Saensouk \& Boonma sp. nov. (A) habit, (B) front and side view of anther, (C) side view of terminal inflorescence in the leaf-sheaths, (D) dorsal corolla lobe, (E) lateral corolla lobe, (F) lateral staminode, $(\mathrm{G})$ labellum, $(\mathrm{H})$ epigynous glands with ovary, (I) calyx; J, bracteole; K, side view of flower. Drawn by Thawatphong Boonma. 

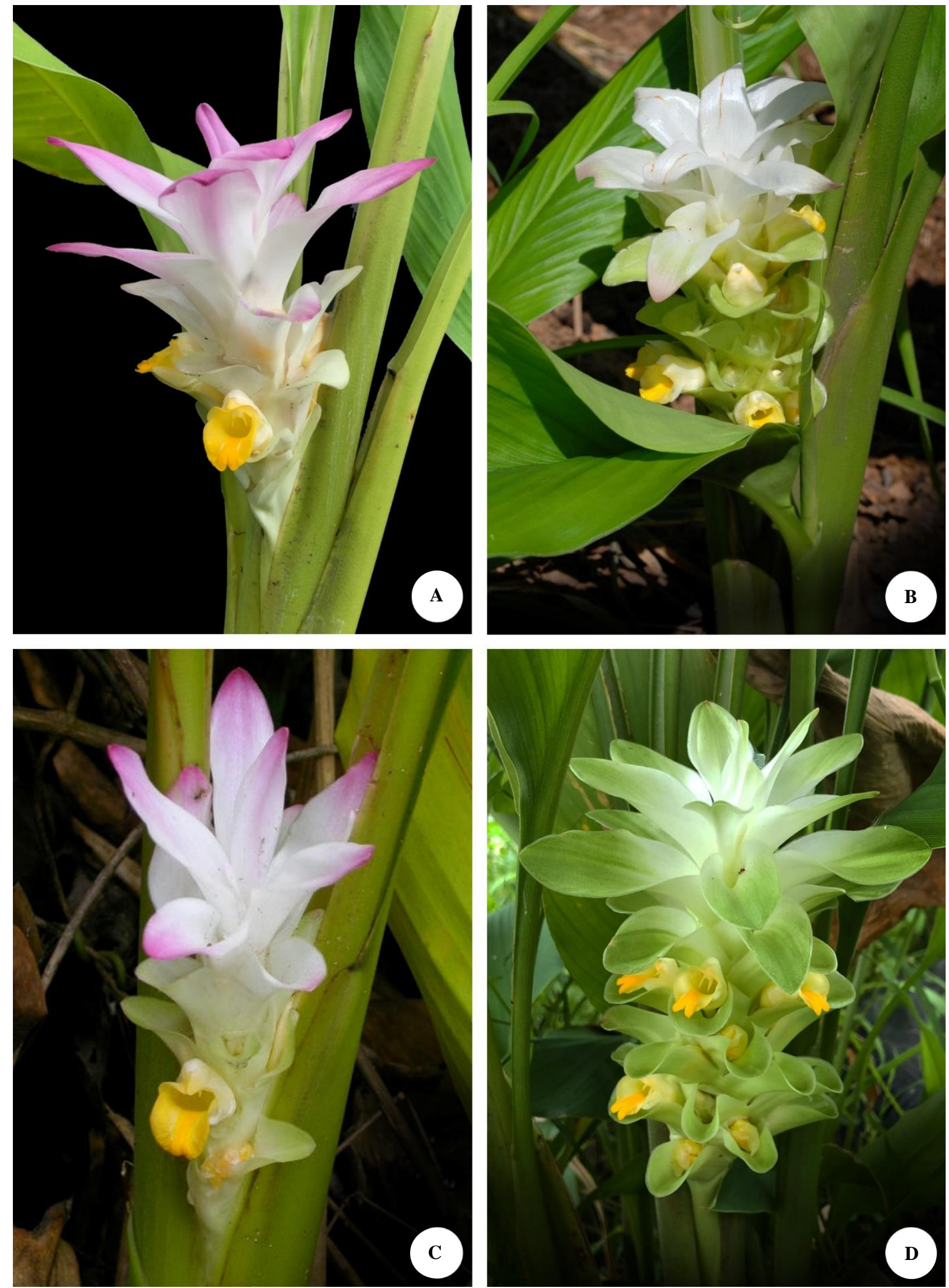

Figure 3. Inflorescence of four Curcuma spp. (A) Curcuma rangjued Saensouk \& Boonma, (B) C. sichuanensis Chen X.X., (C) C. amada Roxb., (D) C. longa L. Photographs: (A) and (D) by Thawatphong Boonma, (B) by Bing Liu from http://plantsoftheworldonline.org/taxon/urn:lsid:ipni.org:names:903993-1, and (C) by Surapon Saensouk. 
A new record of Curcuma cordata Wall. for Thailand

Curcuma cordata Wall., Pl. Asiat. Rar. 1:8-9, 1829 Figures 4-subgenus Curcuma

Type: THAILAND, Mae Hong Son Province, Mae Sariang District, 415 m, 18.09.2019, T.Boonma 17 (KKU)

Perennial herbs $60-120 \mathrm{~cm}$ tall. Rhizome ovoid, 3-5 $\times$ 2-4 cm, brown externally, pale yellow internally, produced 2-3 horizontal branches rhizome in the opposite side, brown externally, pale yellow internally; several root tubers, sub-rotunda to subglobose, 2-3 $\times 1-2$, white internally, developing some distance from the rhizome. Leafy shoot with 3-5 leaves; pseudostem composed of sheathing bracts and leaf sheaths; sheathing bracts 2-3, apex slightly mucronate, drying out and decaying while growing; leaf sheaths distichous, green with reddish-brown tinge, villous; ligule bilobed, hyaline, green with reddish tinge, sparsely hairy, apex obtuse; petiole erect and spreading, up to $25 \mathrm{~cm}$ long (petiole of innermost leaves longest, outermost leaf shortest), canaliculate, green or green with reddish-brown tinge at the base, villous; lamina ovate, $25-40 \times 14-20 \mathrm{~cm}$, apex acuminate, base cordate or retuse, membranous margin, adaxially green, abaxially lighter green, soft and villous, rib green with fine hairy. Inflorescence terminal, in the middle between leaf-sheaths, barely reaching the peak of the pseudostems, erect; peduncle cylindrical between leaf-sheaths, 20-32 cm long, 7-8(-10) mm diam., pale green, villose; spike 15-20(-25) $\mathrm{cm}$ long, 5-6 cm diam. in the middle, villous; coma white to pale green with violet tip, rarely all violet, erect, a little longer than fertile bracts, villous, fused only at base; fertile bracts ovate, $2.5-4 \times 2-3 \mathrm{~cm}$, apex rounded to obtuse, upper bracts with slightly mucronate, villous, pale green with darker green at distal part, a violet tinge always extends more or less downwards upon the exterior margins of the fertile bracts, connate in the lower $1 / 3$ to $1 / 2$ forming a porch; cincinni with 2-3 flowers. Bracteoles one per flower, broadly triangular, 17-22 × 14-17 mm, pubescent, translucent white, apex acute. Calyx tubular, short, 10-12 $\mathrm{mm}$ long, apex 3-toothed, with unilateral incision up to 5 mm long; floral tube slim, cylindrical, 33-36 mm long, internally hairy at the throat, externally yellowish; dorsal corolla lobe narrowly triangular-ovate 13-15 × 4-6 mm, concave, yellowish, apex mucronate, c. $1 \mathrm{~mm}$ long; lateral corolla lobes narrowly triangular-ovate, 12-15 × 4-6 mm, concave, yellowish, apex obtuse. Staminodes irregularly obovate, 9-11 × 5-6 mm, apex rounded, with short fine hairy on the adaxial side, yellow. Labellum broadly obovate to suborbicular with 3-lobed, 14-16 × 13-15 mm, the apex of mid lobe emarginate, incision to $4 \mathrm{~mm}$ long, yellow with a darker yellow median band. Filament flat, 4 $5 \mathrm{~mm}$ long, c. $5 \mathrm{~mm}$ broad at the base; anther $6 \times 2.5-3$ $\mathrm{mm}$, glabrous, yellowish, spurred; spurs triangular, flat, $2-$ $2.5 \mathrm{~mm}$ long, yellowish, apex acute, pointing downwards; anther crest c. $1 \mathrm{~mm}$ long, 1-1.2 mm wide, apex rounded. Epigynous glands two, 4-5 mm long. Style thin, white, glabrous, placed in the groove in a dorsal side of floral tube; stigma c. $1 \times 1 \mathrm{~mm}$; ostiole ciliate. Ovary $3.8-4 \times$ 2.5-3 mm, trilocular, glabrous. Fruit and Seeds not seen.

Ecology: In deciduous forest and bamboo forest, from 220-1,100 m above sea level.

Phenology: Flowering in August to October; flowers open in the morning and last a single day. Leafy shoot emerging in late May and dormancy begins in November.

Distribution: Mandalay and Bago Division (Pegu) of Myanmar, and Mae Hong Son province, northern Thailand.

Uses: Ornamental plants.

Specimen examined: Thailand: Northern; Mae Hong Son province; Larsen et al. 2338, Ban Mae Pang $30 \mathrm{~km}$ North of Mae Sariang, 400 m, 11 July 1968 (AAU!), Larsen et al. 2087, $20 \mathrm{kms}$ W of Bo Luang towards Mae Sariang, 1,100 m, 4 July 1986 (AAU!, BKF!), Larsen et al. 2240, S of Mae Sariang, 220 m, 8 July 1968 (AAU), Maknoi 386, Mae Sariang, Mae Hong Son, 26 July 2003 (AAU!, BKF!, PSU!, QBG!), Maknoi 562, Mae Sariang, Mae Hong Son, 25 July 2004 (AAU!, BKF!, PSU!, QBG!), Maknoi C. 394 (QBG 29156), in the bamboo forest, route from Mae Hong Son to Mae Sariang, Mae Hong Son, 25 July 2003 (QBG!), Suksathan P. 4215 (QBG 30495), 410 m., Mae Hong Son, 23 June 2007 (QBG!), Pongamornkul W. 3497 (QBG 66915), 300 m., in mixed deciduous forest, Ban Sob Mae Pae, Sob Mei, Mae Hong Son, 10 July 2013 (QBG!), Phaosrichai P. \& Wongnak M. 13 (QBG 67703), 451 m., Mae Hong Son, 3 September 2013 (QBG!), Pongamornkul W. \& Panya R. 462 (QBG 15355), 190 m., in mixed deciduous forest, Baan Taa Ruea, Sob Moei, Mae Hong Son, 5 August 1999 (QBG!), Pumicong S. 404 (QBG 28523), on the slope near a stream, Mae Hong Son, 29 August 2006 (QBG!). Additional living and spirit specimens from Mae Hong Son Province, Mae Sariang District, 415 m, 18.09.2019, T.Boonma 170, 171 (BBRG). Myanmar: Wallich N. Cat. No. 6598 (K001124266, EICH number 6598 C), Rangoon; Kress W.J. 98-6166 (USNM 1998133), Toungoo Township, Bago Division, 11 July 1998 (US!), Kress W.J. 99-6435 (USNM 1999119), 240 m., Pyinmana Township, Mandalay Division, 24 June 1999 (US!), Kress W.J. 99-6469 (USNM 1999151 b), 800 m., Kyaukpadaung township, Mandalay Division, 29 June 1999 (US!), Kress W.J. 02-7152 (USNM 2002164), 400 m., Paungpyin township, Bago Division, 13 July 2002 (US!), Kress W.J. 96-5653 (USNM 1996230), 900 m., Kyaukpadaung township, Mandalay Division, 18 May 1996 (US!). 

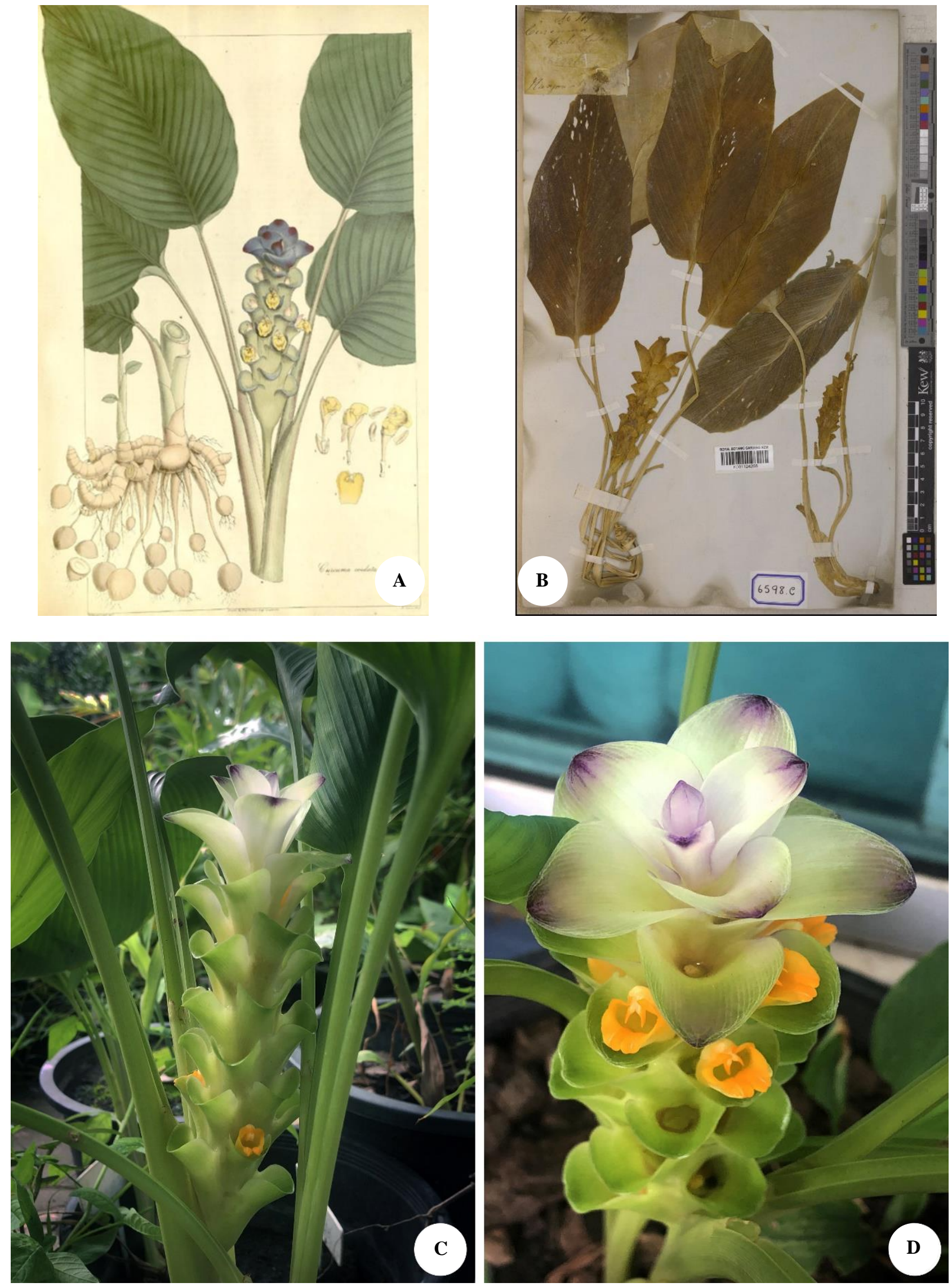

Figure 4. Curcuma cordata Wall. (A) illustration by N. Wallich, (B) specimen of $C$. cordata, Wallich N. Cat. No. 6598, K001124266, (C) inflorescence with flowers-side view, (D) Inflorescence with flowers-oblique view. Photo (A) from Plantae Asiaticae Rariores, Vol. 1 plate 10 (1830),(B) from http://www.kew.org/herbcatimg/717660.jpg, (C) and (D) by Thawatphong Boonma. 
Notes: The flowers of this species are a darker tone of yellow or orange-yellow, while the flowers of $C$. petiolata are pale tone of yellow. The size of $C$. cordata in natural habitat is much larger and statelier and with silky hairs, the leaves are more decidedly cordate, soft, and villous, while in $C$. petiolata are glabrous. The spike is villous whereas $C$. petiolata is smooth. Moreover, this species is also similar to one form of Curcuma aurantiaca in Southern Thailand which has pale green fertile bracts and violet coma, it was called 'Amethyst' but distinguishable by its spurless anther whereas $C$. cordata has calcarate anther.

\section{Key to 28 species of Curcuma subgenus Curcuma in Thailand}

1. Branches rhizome not produced

2. Inflorescence lateral and terminal

2. Inflorescence terminal

3. Sheaths glabrous; leaf abaxially glabrous

3. Sheaths pubescent; leaf abaxially hairy or glabrescent at least at the apex

C. angustifolia

Branches rhizome produced or well developed

4. Inflorescence terminal

5. Rhizome creeping

5. Rhizome with branches non-creeping

6. Anther ecalcarate

7. Flowers yellow or orange-yellow

7. Flowers cream-white with yellow in the center of labellum

6. Anther calcarate

8. Bracts glabrous

9. Ovary glabrous

9. Ovary pubescent

C. antinaia

8. Bracts pubescent

10. Coma bracts greenish-white

10. Coma bracts pink or white with pink at tip

11. Peduncle red

11. Peduncle green

12. Ovary glabrous

13. Leaves glabrous; coma pink

13. Leaves pubescent; coma white with violet tip

12. Ovary pubescent

14. Leaf adaxially green with reddish-purple along the midrib

14. Leaf adaxially green with green midrib

15. Rhizome deep orange-yellow, strongly aromatic

. rubrobracteata

15. Rhizome pale yellowish-white to pale yellow

16. Leaf-abaxially glabrous; rhizome non-aromatic

16. Leaf-abaxially puberulous; rhizome with smell of green mango

C. aurantiaca

C. roscoeana

sattayasaiorum

C. viridiflora

C. phrayawan

C. petiolata

C. cordata

C. wanenlueanga

C. longa

C. rangjued

C. amada

4. Inflorescence usually lateral

17. Leaves lower surface pubescent

18. Leaf-adaxially green with green midrib

19. Rhizome yellow; lamina broadly lanceolate

19. Rhizome pale yellow; lamina oblong

18. Leaf-adaxially green with red or reddish-purple patch along midrib

20. Bracts glabrous

20. Bracts pubescent

21. Inflorescence cylindrical $>10 \mathrm{~cm}$ long; bracts green, short-hairy on both surfaces

21. Spike almost globular shape $<10 \mathrm{~cm}$ long; bract bright green to brownish green with pale green venation, adaxially puberulent, abaxially glabrous

17. Leaves lower surface glabrous

22. Petioles and leaf-sheaths reddish-brown

22. Petioles and leaf-sheaths green

23. Leaf-adaxially green with red or reddish-purple patch along the midrib

24. Rhizome aeruginous green

24. Rhizome yellow or orange

25 . Corolla lobes nearly white or with very slight pinkish shade; rhizome pale straw to yellowish-white

25. Corolla lobes conspicuously pink to reddish; rhizome deep bright orange to yelloworange

23. Leaf-adaxially green without red patch along midrib

26. Fertile bracts pale pink; rhizome pale ochraceous

26. Fertile bracts green; rhizome white to pale yellow

27. Bracts glabrous

27. Bracts minutely puberulous on both sides

C. aromatica

C. elata

C. zedoaroides

C. latifolia

C. globulifera

C. rubescens

C. aeruginosa

C. picta

C. zanthorrhiza

C. comosa

C. leucorrhiza

C. mangga 


\section{ACKNOWLEDGMENTS}

This research project is financially supported by National Science and Technology Development Agency (FDA-CO-2563-11240-TH). We thank Walai Rukhavej Botanical Research Institute, Mahasarakham University, Brio Garden (BBRG), our family, and botanist friends for their facilities and support during this study although in the hardest time of the Covid-19 pandemic. And also warm thanks to all curators of all herbaria visited (BK, BKF, K, KKU, NMNH, QBG, US).

\section{REFERENCES}

Araujo CC, Leon LL. 2001. Biological activities of Curcuma longa L. Mem Inst Oswaldo Cruz 96: 723-728. DOI: 10.1590/S007402762001000500026

Chen XX. 1984. A new species of Curcuma Roxb. Guihaia 4 (2): 133 134.

Kew Science. 2021. World Checklist of selected plant families (WCSP) http://apps.kew.org/wcsp/

Larsen K, Larsen SS. 2006. Gingers of Thailand. Queen Sirikit Botanic Garden, The Botanical Garden Organization, Chiang Mai.
Leong-Škorničková J, Šida O, Marhold K. 2010. Back to types! Towards stability of names in Indian Curcuma L. (Zingiberaceae). Taxon 59 (1): 269-282. DOI: 10.1002/tax.591025

Leong-Škorničková J, Šida O, Záveská E, Marhold K. 2015. History of infrageneric classification, typification of supraspecific names, and outstanding transfers in Curcuma (Zingiberaceae). Taxon 64 (2): 362373. DOI: $10.12705 / 642.11$

Oranuch K. 2007. Herb in Zingiberaceae. Biotechnology Research and Development Office, Bangkok.

Roxburgh W. 1810. Descriptions of several of the Monandrous Plants of India (Curcuma). Asiatic Res 11: 329-342.

Roxburgh W. 1829. Plantae Asiaticae Rarores; or, Descriptions and figures of a select number of unpublished east Indian plants 1: 8-9.

Sabu M. 2006. Zingiberaceae and Costaceae of South India. Indian Association for Angiosperm Taxonomy, Calicut University, Kerala.

Saensouk S, Boonma T, Saensouk P. 2021a. Six new species and a new record of Curcuma L. (Zingiberaceae) from Thailand. Biodiversitas 22 (4): 1658-1685. DOI: 10.13057/biodiv/d220410.

Saensouk S, Boonma T, Thomudtha A, Thomudtha P, Saensouk P. 2021 b. Curcuma wanenlueanga (Zingiberaceae), a new species of subgenus Curcuma from Thailand. Biodiversitas 22 (7): 2988-2994. DOI: 10.13057/biodiv/d220410

Sirirugsa P, Larsen K, Maknoi C. 2007. The genus Curcuma L. (Zingiberaceae): Distribution and classification with reference to species diversity in Thailand. Gard Bull Sing 59 (1\&2): 203-220.

Záveská E, Fér T, Šida O, Krak K, Marhold K, Leong-Škorničková J. 2012. Phylogeny of Curcuma (Zingiberaceae) based on plastid and nuclear sequences: Proposal of the new subgenus Ecomata. Taxon 61 (4): 747-763. DOI: $10.1002 /$ tax.614004 